Dhaka Univ. J. Sci. 64(2): 157-161, 2016 (July)

\title{
Structural, Spectroscopic and Optical Properties of Monohydrated Adenine: A Theoretical Study
}

\author{
M. Alauddin ${ }^{1}$, M. M. Islam² and M. A. Aziz ${ }^{3}$ \% \\ ${ }^{1}$ Department of Chemistry, University of Barisal, Barisal-8200, Bangladesh \\ ${ }^{2}$ Mulliken Center for Theoretical Chemistry, Institut für Physikalische und Theoretische Chemic, Universität Bonn, \\ Beringstraße 4-6, D-53115 Bonn, Germany \\ ${ }^{3}$ Department of Chemistry, Dhaka University, Dhaka-1000, Bangladesh
}

(Received: 14 February 2016; Accepted: 6 June 2016)

\begin{abstract}
The structural, spectroscopic (IR, NMR and UV-Vis), electronic and optical properties of monohydrated adenine (monohydrated 6-aminopurine, $\mathrm{C}_{5} \mathrm{H}_{5} \mathrm{~N}_{5} \cdot \mathrm{H}_{2} \mathrm{O}$ ) are investigated theoretically using DFT/B3LYP level of theory. Three minimum energy structures have been identified for monohydrated of adenine where $\mathrm{H}_{2} \mathrm{O}$ molecule is doubly hydrogen bonded with adenine. ${ }^{1} \mathrm{H}$ NMR analysis shows that the protons which are hydrogen bonded become deshielded and chemical shift moves to the higher frequency region.Five IR active mode of vibrations were found at $3108,3295,3665,3676$ and $3719 \mathrm{~cm}^{-1}$ which are assigned as bonded $-\mathrm{OH}$ vibration of $\mathrm{H}_{2} \mathrm{O}$, Bonded $-\mathrm{NH}$ vibration of $\mathrm{NH}_{2}$, Free $-\mathrm{NH}$ vibration of adenine $(9 \mathrm{~N})$, Free $-\mathrm{NH}$ vibration of $\mathrm{NH}_{2}$, Free $-\mathrm{OH}$ vibration of $\mathrm{H}_{2} \mathrm{O}$, respectively and agree well with the available experimental results. The investigation of electronic properties shows that the HOMO-LUMO band gap energy of monohydrated adenine at B3LYP level is $5.15 \mathrm{eV}$. The major electronic transition (from HOMO to LUMO $(83 \%)\left(\pi \rightarrow \pi^{*}\right)$ ) occurs at $258 \mathrm{~nm}(4.80 \mathrm{eV})$ with a minor transition at $237 \mathrm{~nm}(5.23 \mathrm{eV})$. Theoretically it is observed that the HOMO-LUMO band gap energy is for monohydrated adenine is lower than that of adenine.
\end{abstract}

Keywords: Monohydratedadenine, TD-DFT, IR, NMR, Electronic properties, Optical absorption

\section{Introduction}

Knowledge of the photophysics and photochemistry of individual nucleic acid bases or base pairs is a prerequisite for a detailed understanding of DNA photostability under ultraviolet (UV) irradiation. Because, nucleobases absorb UV light strongly and act as a primary chromophores of DNA. ${ }^{-5}$ Photostability of DNA bases is the essential criteria for the preservation of genetic information of DNA bases. In solvated DNA bases, understanding the role of solvent for the stability of DNA bases is very important. As we know that Hydrogen-bonds (HB) play an important role in molecular systems, particularly in biological systems, because all lives on the earth may be viewed as a matter of hydrogen-bonding supramolecular systems. Since HBs have a central role on the mechanism of life phenomena including the structure and functions, it is essential to understand the molecular-level aspects of HB systems. Besides the basic science view, molecular-level understating of HB systems is also important for synthesis and design of highly specific drugs. This is because the intermolecular interaction, controls the working activity of a drug is determined by the specific interaction and binding constant of $\mathrm{HB}$ complexes such as those between drugs and DNA, RNA or protein. ${ }^{6-7}$

Numerous experimental and theoretical studies on DNA and DNA bases have been performed to understand structural, electronic properties and excited state lifetimes. ${ }^{8-11}$ All the calculations have been focused on the ground state to the higher electronic singlet and triplet states of the neutral molecules.

In this paper, we have performed a theoretical investigation of structural, spectroscopic, electronic and optical properties of monohydrated adenine with DFT method and compared with the available experimental data.

\footnotetext{
* Author for correspondence. e-mail: azizttma@yahoo.com
}

\section{Computational Details}

All the calculations have been performed using well known hybrid approach $\mathrm{B}^{2} \mathrm{LYP}^{12}$ as implemented in the quantum chemistry package G09. ${ }^{13}$ We have used $6-31 \mathrm{G}$ basis set in order to calculate the structure, IR, ${ }^{1} \mathrm{H}$ NMR and UV-Vis spectra of monohydrated adenine in the ground state at the B3LYP level of theory. The optimized structure of monohydrated adenine in the ground state was verified by calculating vibrational frequencies to confirm that there were no imaginary frequencies. Excited state calculations have been done by TD-DFT method employing the same basis set and theory to study electronic and optical properties of monohydrated adenine. To avoid complexity, we have calculated only six excited states of monohydrated adenine.

\section{Results and Discussion}

\section{Molecular Geometry and Thermodynamic parameters}

The optimized structure of monohydrated adenine by B3LYP is shown in Fig. 1. In order to get optimized minimum energy structure of monohydrated adenine, at first we have done intrinsic reaction coordinate (IRC) calculation with $\mathrm{HF} / 6-31 \mathrm{G}$. This minimum energy structure was reoptimized using DFT/B3LYP/6-31G level of theory.

The final geometry corresponds to true energy minima as revealed by the lack of imaginary frequencies in the vibrational mode calculation. Several structures of monohydrated adenine have been calculated to see the hydration site of adenine. Among them, three structures (Structure I, Structure II and Structure III) are found for minimum energy which is shown in Fig. 1. The most stable structure is structure I where $\mathrm{H}_{2} \mathrm{O}$ molecule is connected with adenine via two hydrogen bonding. 


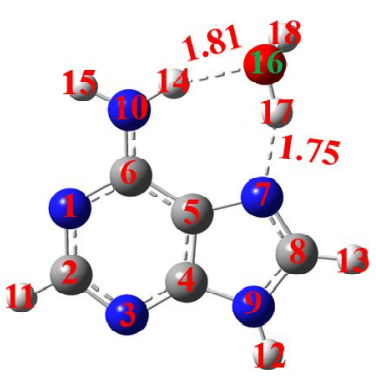

Structure I $(0 \mathrm{eV})$

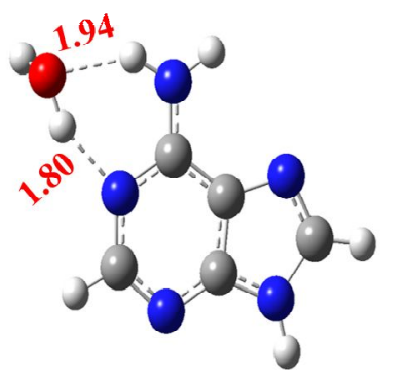

Structure II

$(0.1130 \mathrm{eV})$

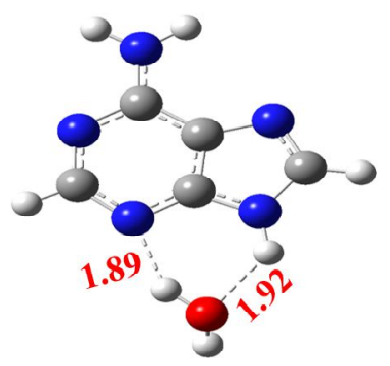

Structure III

$(0.1267 \mathrm{eV})$

Fig. 1. Three optimized structures of monohydrated adenine.

One hydrogen of $\mathrm{H}_{2} \mathrm{O}$ molecule is connected with nitrogen atom ( 7 position) and oxygen atom of $\mathrm{H}_{2} \mathrm{O}$ is connected with amino group of adenine. The second most stable one is structure II where one hydrogen of $\mathrm{H}_{2} \mathrm{O}$ molecule is connected with nitrogen atom (1 position) and oxygen atom of $\mathrm{H}_{2} \mathrm{O}$ is connected with amino group of adenine. Structure I is more stable than structure II by $0.1130 \mathrm{eV}$. In case of structure III, one hydrogen of $\mathrm{H}_{2} \mathrm{O}$ molecule is connected with nitrogen atom ( 3 position) and oxygen atom of $\mathrm{H}_{2} \mathrm{O}$ is connected with hydrogen atom ( 9 position) of adenine. Structure I is more stable than structure III by $0.1267 \mathrm{eV}$.

The total energy (SCF), zero point vibrational energy (ZPVE), rotational constants, specific heat capacity $(\mathrm{CV})$ at constant volume, entropy(S) and dipole moment of monohydrated adenine for the most stable structure are provided in the Table 1.

Table 1. Calculated thermodynamic parameters of monohydrated adenine

\begin{tabular}{|l|c|c|c|c|c|c|}
\hline Molecule & $\begin{array}{c}\text { SCF energy/ } \\
\text { Hatree }\end{array}$ & $\begin{array}{c}\mathrm{Z} \text { PV energy/ } \\
\mathrm{kcal} \mathrm{mole}\end{array}$ & $\begin{array}{c}\text { Rotational } \\
\text { constant } / \mathrm{GHz}\end{array}$ & $\begin{array}{c}\text { Specific } \\
\text { heat }(\mathrm{Cv}) / \mathrm{cal} \\
\mathrm{mol}^{-1} \mathrm{~K}^{-1}\end{array}$ & $\begin{array}{c}\text { Entropy(S)/ } \\
\mathrm{cal} \mathrm{mol}^{-1} \mathrm{~K}^{-} \\
1\end{array}$ & $\begin{array}{c}\text { Dipole } \\
\mathrm{moment}^{\prime} \mu \\
/ \mathrm{Debye}^{-}\end{array}$ \\
\hline $\begin{array}{l}\text { Hydrated } \\
\text { Adenine }\end{array}$ & -543.5937 & 87.2050 & $\begin{array}{c}1.52627 \quad 1.10294 \\
0.64144\end{array}$ & 35.554 & 9.339 & 5.3917 \\
\hline
\end{tabular}

$\mathrm{SCF}=$ Self-Consistent Field and ZPV= Zero Point Vibrational

\section{${ }^{1} H N M R$ spectral analysis}

For structural analysis of organic compounds, NMR spectroscopy is one of the most powerful techniques. It is well-established that the combined use of experimental NMR spectroscopic technique and computational simulation methods give a powerful gadget to interpret and predict the structure of organic compound, even for the structures of large biomolecules. To get theoretical ${ }^{1} \mathrm{H}$ NMR results of monohydrated adenine, first the full geometry optimization is carried out with the B3LYP/6-31G in gas phase. After optimization, ${ }^{1} \mathrm{HNMR}$ calculations of the studied compounds are calculated by using the gauge-including atomic orbital (GIAO) method. The chemical shifts of the studied compounds are reported in $\mathrm{ppm}$ relative to tetramethylsilane (TMS) for ${ }^{1} \mathrm{H}$ NMR spectrum as presented in Table 2. The chemical shift of $\mathrm{H}(14), \mathrm{H}(11), \mathrm{H}(17)$, $\mathrm{H}(12) \mathrm{H}(13), \mathrm{H}(15)$ and $\mathrm{H}(18)$ protons (See Fig.1 for labeling) are found at $8.15,7.84,6.88,6.53,6.38,3.43$ and -0.25 ppm, respectively.
Table 2. Calculated ${ }^{1}$ H NMR data of monohydrated adenine

\begin{tabular}{|c|c|c|c|}
\hline \multirow{4}{*}{ Molecule } & $\begin{array}{c}\text { Protons } \\
\text { with } \\
\text { number }\end{array}$ & $\begin{array}{c}\text { Chemical } \\
\text { Shift } \\
\text { (Calc.)/ppm }\end{array}$ & $\begin{array}{c}\text { Chemical } \\
\text { Shift } \\
\text { (Expt.)/ppm }\end{array}$ \\
\hline \multirow{5}{*}{$\mathrm{A}\left(\mathrm{H}_{2} \mathrm{O}\right)$} & $\mathrm{H}(14)$ & 8.15 & \\
\cline { 2 - 4 } & $\mathrm{H}(11)$ & 7.84 & 8.14 \\
\cline { 2 - 4 } & $\mathrm{H}(17)$ & 6.88 & \\
\cline { 2 - 4 } & $\mathrm{H}(12)$ & 6.53 & \\
\cline { 2 - 4 } & $\mathrm{H}(13)$ & 6.38 & \\
\cline { 2 - 4 } & $\mathrm{H}(15)$ & 3.43 & \\
\cline { 2 - 4 } & $\mathrm{H}(18)$ & -0.25 & \\
\hline
\end{tabular}

We know that electron rich atom increases the shielding and moves the resonance towards lower frequency and electronwithdrawing atom can decrease the shielding and moves the 
resonance of attached proton towards higher frequency. Similar results were found for monohydrated adenine. Amino proton of $\mathrm{H}(14)$ becomes de-dshielded due to the hydrogen bond with oxygen atom of $\mathrm{H}_{2} \mathrm{O}$ molecule. Therefore the resonance moves to the higher frequency region $(8.15 \mathrm{ppm})$. On the other hand, amino proton of $\mathrm{H}(15)$ which is shielded and moves the resonance towards lower frequency region (3.43 ppm). Similarly $\mathrm{H}(17)$ of $\mathrm{H}_{2} \mathrm{O}$ which is hydrogen bonded with $\mathrm{N}(7)$ atom shows chemical shift at $6.88 \mathrm{ppm}$ as oxygen is more electron negative than nitrogen. The free $\mathrm{H}(18)$ of $\mathrm{H}_{2} \mathrm{O}$ which is so shielded that shows chemical shift near to tetramethylsilane (TMS). The experimental ${ }^{1} \mathrm{H}$ NMR spectra of adenine range between 8.11-8.12 ppm in presence of water solvent. ${ }^{14}$ Our calculated values show deviation from the experimental results, probably because lack of incorporating solvent effect in our calculations.

\section{Vibrational spectral analysis}

The assignments of the vibrational frequencies of monohydrated adenine (calculated and observed) are shown in Table 3. In the calculated spectrum of monohydrated adenine, five IR active mode of vibrations were found at $3108,3295,3665,3676$ and $3719 \mathrm{~cm}^{-1}$ which are assigned as bonded $-\mathrm{OH}$ vibration of $\mathrm{H}_{2} \mathrm{O}$, bonded $-\mathrm{NH}$ vibration of $\mathrm{NH}_{2}$, Free $-\mathrm{NH}$ vibration of adenine $(9 \mathrm{~N})$, Free $-\mathrm{NH}$ vibration of $\mathrm{NH}_{2}$, Free $-\mathrm{OH}$ vibration of $\mathrm{H}_{2} \mathrm{O}$, respectively. Five IR absorption bands at 3210, 3050, 3441, 3451 and $3721 \mathrm{~cm}^{-1}$ were also observed experimentally which are assigned as bonded $-\mathrm{OH}$ vibration of $\mathrm{H}_{2} \mathrm{O}$, Bonded $-\mathrm{NH}$ vibration of $\mathrm{NH}_{2}$, Free $-\mathrm{NH}$ vibration of adenine $(9 \mathrm{~N})$, Free -NH vibration of $\mathrm{NH}_{2}$, Free $-\mathrm{OH}$ vibration of $\mathrm{H}_{2} \mathrm{O}$, respectively. ${ }^{15}$ Therefore we concluded that our theoretical vibrational frequencies have well agreement with the experimental data.

Table 3. IR calculated and experimental frequencies of monohydrated adenine

\begin{tabular}{|c|c|c|c|}
\hline \multirow{2}{*}{ Molecule } & $\begin{array}{c}\text { IR calculated } \\
\text { frequencies/cm }\end{array}$ & $\begin{array}{c}\text { IR experimental } \\
\text { frequencies } / \mathrm{cm}^{-1}\end{array}$ & IR active mode of vibration \\
\hline \multirow{3}{*}{$\mathrm{A}\left(\mathrm{H}_{2} \mathrm{O}\right)$} & 3108 & - & Bonded $-\mathrm{OH}$ vibration of $\mathrm{H}_{2} \mathrm{O}$ \\
\cline { 2 - 4 } & 3097 & 3050 & Bonded $-\mathrm{NH}$ vibration of $\mathrm{NH}_{2}$ \\
\cline { 2 - 4 } & 3445 & 3441 & Free $-\mathrm{NH}$ vibration of adenine $(9 \mathrm{~N})$ \\
\cline { 2 - 4 } & 3455 & 3451 & Free $-\mathrm{NH}$ vibration of $\mathrm{NH}_{2}$ \\
\cline { 2 - 4 } & 3719 & 3721 & Free -OH vibration of $\mathrm{H}_{2} \mathrm{O}$ \\
\hline
\end{tabular}

Calculated values were corrected by multiplying the frequency factor, $f=0.940$

Electronic absorption and optical properties

We have used TD-DFT method for the calculations of excited state properties of monohydrated adenine. For this purpose, we have calculated six lowest singlet electronic states in the ground state of monohydrated adenine. The computed electronic values such as absorption wavelength $(\lambda)$, excitation energies (E) and oscillator strengths (f) are tabulated in Table 4.

Table 4. Calculated wavelengths $\lambda(\mathrm{nm})$, excitation energies $\mathrm{E}(\mathrm{eV})$ and oscillator strength (f) and major\& minor electronic transitions of monohydrated adenine

\begin{tabular}{|c|c|c|c|c|}
\hline Molecule & $\lambda(\mathrm{nm})$ & $\mathrm{E}(\mathrm{eV})$ & $\mathrm{f}$ & Major and minor transitions \\
\hline \multirow{3}{*}{$\mathrm{A}\left(\mathrm{H}_{2} \mathrm{O}\right)$} & 258 & 4.80 & 0.1504 & $\mathrm{H} \rightarrow \mathrm{L}(83 \%), \mathrm{H} \rightarrow \mathrm{L}+1(10 \%)$, \\
& & & & $\mathrm{H}-2 \rightarrow \mathrm{L}(3 \%) \& \mathrm{H} \rightarrow \mathrm{L}+2(2 \%)$ \\
\cline { 2 - 5 } & 237 & 5.23 & 0.0481 & $\mathrm{H}-2 \rightarrow \mathrm{L}(14 \%), \mathrm{H} \rightarrow \mathrm{L}(10 \%) \mathrm{H} \rightarrow \mathrm{L}+1(70 \%)$ \\
\hline
\end{tabular}

$$
\mathrm{H}=\mathrm{HOMO} \& \mathrm{~L}=\mathrm{LUMO}
$$

The major transition with highest oscillator strength for monohydrated adenine is at $258 \mathrm{~nm}(4.80 \mathrm{eV})$. The major transition occurs from HOMO to $\operatorname{LUMO}(83 \%)\left(\pi \rightarrow \pi^{*}\right)$ with a minor transitions from HOMO to LUMO+1 (10\%), HOMO-2 to LUMO (3\%) and HOMO to LUMO +2 (2\%). The HOMO and LUMO that participate in the lowest electronic transitions of monohydrated adenine are presented in Fig. 2 


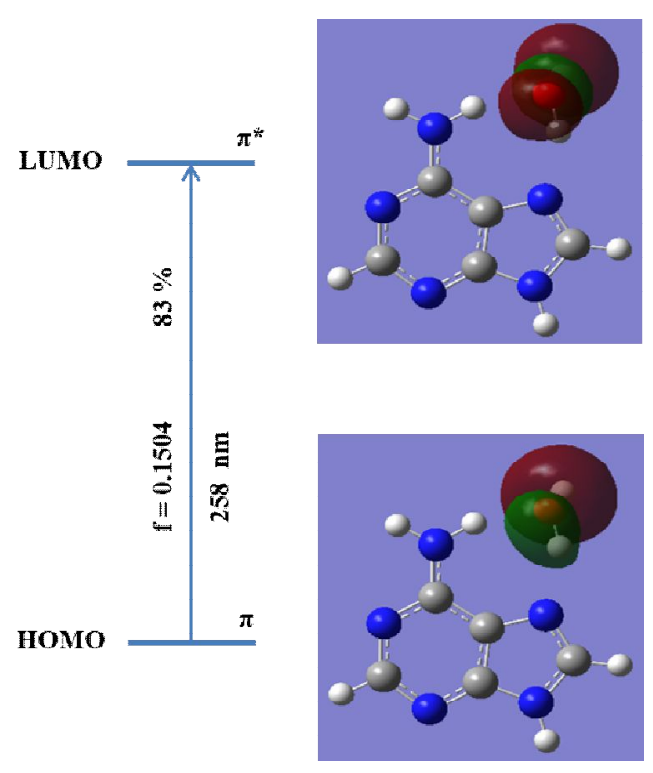

Fig. 2. Transition of HOMO $\rightarrow$ LUMO of monohydrated adenine.

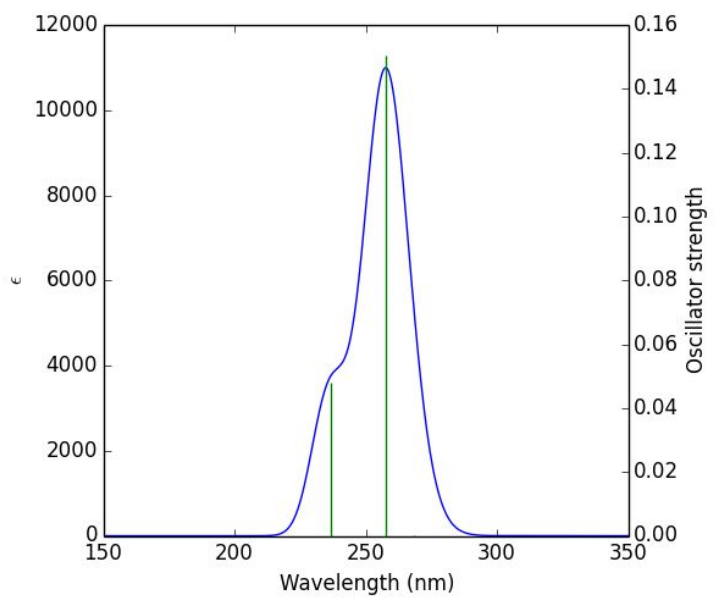

Fig. 3. Calculated UV-Visible absorption spectrum of adenine.

In the present study, the FMO energy gap is calculated as the energy difference between the highest occupied molecular orbital (HOMO) and the lowest unoccupied molecular orbital (LUMO) as follows:

$$
\begin{aligned}
& \mathrm{HOMO}_{\text {energy }}(\mathrm{B} 3 \mathrm{LYP})=-6.02 \mathrm{eV}, \\
& \mathrm{LUMO}_{\text {energy }}(\mathrm{B} 3 \mathrm{LYP})=-0.87 \mathrm{eV} \\
& \mathrm{HOMO}-\mathrm{LUMO} \text { energy gap }(\mathrm{B} 3 \mathrm{LYP})=5.15 \mathrm{eV}
\end{aligned}
$$

Therefore the energy gap of FMO of monohydrated adenine is $5.15 \mathrm{eV}$.
Previously we studied pure adenine ${ }^{16}$ and found the energy gap of FMO of is $5.35 \mathrm{eV}$ whereas $5.15 \mathrm{eV}$ for monohydrated adenine. Therefore we can conclude that hydration decreases HOMO-LUMO energy gap and makes electronic transition easier.

\section{Conclusion}

The effect of hydration on the structural, thermodynamics, spectroscopic and electronic properties of adenine has been studied theoretically. Density Functional Theory (DFT) calculations have been performed with Gaussian 09W program at B3LYP/6-31G levels of theory and excited state calculations have been performed by Time-Dependent Density Functional Theory (TD-DFT). Three minimum energy structures have been found for monohydrated adenine where $\mathrm{H}_{2} \mathrm{O}$ molecule is doubly hydrogen bonded with adenine. $\mathrm{H}(14) \& \mathrm{H}(17)$ protons become de-shielded due to the hydrogen bonding and hence resonance frequency moves to higher frequency region. The calculated IR active mode of vibrations and their assignments are in reasonable agreement with the available experimental data. The investigation of electronic properties shows that the HOMOLUMO energy band gap of monohydrated adenine at B3LYP level is $5.15 \mathrm{eV}$. The calculation of optical properties at excited states shows that the major transition (from HOMO to LUMO (83\%) $\left(\pi \rightarrow \pi^{*}\right)$ occurs at $258 \mathrm{~nm}$ $(4.80 \mathrm{eV})$ with a minor transition at $237 \mathrm{~nm}(5.23 \mathrm{eV})$.

\section{Acknowledgement}

This work was supported by the Dean Office, Faculty of Science, University of Dhaka for the postdoctoral research of Dr. M. Alauddin.

\section{References}

1. Crespo-Hernandez C. E., B. Cohen, P. M. Hare, B. Kohler, 2004. Ultrafast Excited-State Dynamics in Nucleic Acids, Chem. Rev.104, 1977.

2. Pecourt J. M. L., J. Peon, B. Kohler, 2001. DNA ExcitedState Dynamics: Ultrafast Internal Conversion and Vibrational Cooling in a Series of Nucleosides, J. Am. Chem. Soc., 123, 13078.

3. Luhrs D. C., J. Viallon, I. Fischer, 2001. Excited state spectroscopy and dynamics of isolated adenine and 9methyladenine, Phys. Chem. Chem. Phys.3, 1827.

4. Zierhut M., W. Roth, I. Fischer, 2004. Dynamics of H-atom loss in adenine, Phys. Chem. Chem. Phys.6, 5178.

5. Kang H., K. T. Lee, B. Jung, Y. J. ko, S. K. Kim, 2002. Intrinsic Lifetimes of the Excited State of DNA and RNA Bases, J. Am. Chem. Soc.124, 12958.

6. De Vries M. S., P. Hobza, 2007. Gas-Phase Spectroscopy of Biomolecular Building Blocks, Annu. Rev. Phys. Chem.58, 585.

7. Perrin C. L., J. B. Nielson, 1997. "STRONG” HYDROGEN BONDS IN CHEMISTRY AND BIOLOGY, Annu. Rev. Phys. Chem. 48, 511.

8. Middleton C. T., K. D. L. Harpe, C. Su, Y. K. Law, C. E. C. Hernandez, B. Kohler, 2009. DNA Excited-State Dynamics: From Single Bases to the Double Helix, Annu. Rev. Phys. Chem. 60, 217-39. 
9. Ghane T., G. Brancolini, D. Varsano, R. D. Felice, 2012. Optical Properties of Triplex DNA from Time-Dependent Density Functional Theory, J. Phys. Chem. B 116, 1069310702.

10. Varsano D., R. D. Felice, M. A. L. Marques, A. Rubio, 2006. A TD-DFT Study of the Excited States of DNA Bases and Their Assemblies. J. Phys. Chem. B 110, 7129-7138.

11. Sobolewski A. L., W. Domcke, 2002. On the mechanism of nonradiative decay of DNA bases: ab initio and TD-DFT results for the excited states of $9 \mathrm{H}$-adenine. Eur. Phys. J. D. 20 369-374.

12. Becke A. D., 1993. Density-functional thermochemistry. III. The role of exact exchange. J. Chem. Phys. 98, 5648-5652.

13. Frisch M. J., G.W. Trucks, H.B. Schlegel, G.E. Scuseria, M.A. Robb, J.R. Cheeseman, G. Scalmani, V. Barone, B. Mennucci, G.A. Petersson, H. Nakatsuji, M. Caricato, X. Li, H.P. Hratchian, A.F. Izmaylov, J. Bloino, G. Zheng, J.L. Sonnenberg, M. Hada, M. Ehara, K. Toyota, R. Fukuda, J. Hasegawa, M. Ishida, T. Nakajima, Y. Honda, O. Kitao, H. Nakai, T. Vreven, J.A. Montgomery Jr., J.E. Peralta, F. Ogliaro, M. Bearpark, J.J. Heyd, E. Brothers, K.N. Kudin, V.N. Staroverov, R. Kobayashi, J. Normand, K. Raghavachari, A. Rendell, J.C. Burant, S.S. Iyengar, J. Tomasi, M. Cossi, N. Rega, N.J. Millam, M. Klene, J.E. Knox, J.B. Cross, V. Bakken, C. Adamo, J. Jaramillo, R. Gomperts, R.E. Stratmann, O. Yazyev, A.J. Austin, R. Cammi, C. Pomelli, J.W. Ochterski, R.L. Martin, K. Morokuma, V.G. Zakrzewski, G.A. Voth, P. Salvador, J.J. Dannenberg, S. Dapprich, A.D. Daniels, O. Farkas, J.B. Foresman, J.V. Ortiz, J. Cioslowski, D.J Fox, Gaussian, Inc., Wallingford CT, 2009.
14. Human Metabolome Data Base (HMDB0034)/1H NMR spectrum of adenine: $500 \mathrm{MHz}$ in $\mathrm{H}_{2} \mathrm{O}$. (http://www.hmdb.ca/ metabolites/HMDB00034).

15. Alauddin, M., M. Roy, J. K. Song, S. M. Park, 2015. Infrared photo dissociation of adenine $\operatorname{dimer}\left(\mathrm{H}_{2} \mathrm{O}\right) \mathrm{n}^{+}(\mathrm{n}=1-4)$ clusters, Intl. J. Mass Spectrom. 381, 41-47.

16. Alauddin M., M. M. Islam, M. K. Hasan, T. Bred wand M. A. Aziz, 2015. A Theoretical Investigation of the Structural, Spectroscopic and Optical Properties of Adenine, Dhaka Univ. J. Sci. 64(1), 77-81. 
